\title{
PEMBERIAN DANA DESA KEPADA DESA ADAT DI BALI
}

\author{
Oleh : \\ Ni Putu Wilda Karismawati ${ }^{1}$
}

\begin{abstract}
There are two types of villages in government system of Bali Province, these are the Official Village and the Customary Village. The Financial division of these two Villages in Bali is expected to be regulated fairly because those two villages are recognized their existences, otherwise the provision of rural funding must also be given to these two villages. Nevertheless, the Regulation of Minister of Domestic Affairs No. 113 Year 2014 concerning on Financial Management does not regulate the usage of funds for the Customary Village.

This study applied research of normative law that beganl. From the void norm in the provision of rural funds to the Customary Villages in Bali. Thus, the result of this research is the provision of rural funds to the Customary Village based on the Regulation of the Minister of Domestic Affairs No. 37 year 2007 concerning on Guidelines for Rural Financial Management and Regulation of Minister of Rural Affairs No. 5 year 2015 about Priority of Village Fund Usage year 2015. Meanwhile the responsibility is undertaken by the Customary Village which the funds were transferred first to Village Revenues and Expenditures Budget (APBDes) of Oficial Village, therefore the Customary Village are obliged to make Responsibility Report (SPJ) in each use of funds.
\end{abstract}

Key Words : Customary Village, Financial Responsibility, Rural Finance

\section{PENDAHULUAN}

\subsection{Latar Belakang}

Indonesia merupakan Negara yang terbentuk dari tiga unsur yang membentuknya yaitu memiliki rakyat, memiliki wilayah yang jelas dan memiliki suatu pemerintahan yang berdaulat. Keanekaragaman negara indonesia terlihat dalam berbagai etnis suku, golongan, agama serta kebudayaan yang beranekaragam,sedangkanwilayahindonesia yang merupakan wilayah yang luas yang terdiri dari ribuan pulau-pulau besar maupun kecil. ${ }^{2}$ Sebagai suatu bangsa yang memiliki

Mahasiswa Magister (S2) Ilmu Hukum Universitas Udayana, Denpasar, Bali, Alamat: Br. Kaliakah, Ds. Kaliakah, Kec. Negara, Kab. Jembrana, Bali, email: wildakharisma91@gmail.com

2 Kaelan, 2004, Pendidikan Pancasila, Paradigma, Yogyakarta, hlm.124. kemajemukan serta keanekaragaman yang terbentuk dari berbagai kepulauan yang memiliki suku bangsa, kebudayaan serta agama yang berbeda-beda sehingga menjadi suatu kesatuan yang tidak tidak bisa dilepaskan sebagai ciri khas bangsa Indonesia.

Menurut Korn yang menyatakan bahwa desa sebagai suatu Negara kecil yang disebut dengan Republik Desa. ${ }^{3}$ Republik desa yang dimaksud oleh Korn disini ialah desa adat memiliki sistem pemerintahannya sendiri yang merupakan otonomi asli dari desa tersebut.

\footnotetext{
I Made Suastawa Dharmayuda, 2001, Desa Adat Kesatuan Masyarakat Hukum Adat di Provinsi Bali, Upada Sastra, Denpasar, hlm.5.
} 
Desa merupakan bahasa yang sering digunakan oleh masyarakat bali yang merupakan kata yang berasal dari bahasa bali, yang mana bahasa bali tersebut bersumber dari bahasa sansekerta. Menurut Soetardjo, kata desa merupakan kata sansekerta yang memiliki arti tanah air atau tanah kelahiran. ${ }^{4}$

Desa di Bali merupakan pemerintahan dibawah kabupaten/kota tidak dibawah kecamatan. Pemerintahan desa di bali memiliki otonomi yaitu otonomi desa, otonomi desa yang dimaksud disini ialah otonomi yang didasarkan pada hak asal usul dan adat istiadat. ${ }^{5}$ Di Bali dalam suatu wilayah desa terdapat dua jenis desa, yaitu Desa Dinas dan Desa Adat. Desa Dinas maupun Desa Adat di Bali memiliki fungsi yang berbeda-beda. Desa Dinas menjalankan fungsi penyelenggaraan pemerintahan, sedangkan Desa Adat menjalankan fungsi penyelenggaraan urusan adat dan agama.

Dalam penyelenggaraan pemerintahan Desa Adat maupun Desa Dinas di Bali tentunyamemerlukandanadalampelaksanaan kegiatan desanya tersebut. Pendapatan Desa yang didapat oleh suatu desa di Bali yaitu yang memiliki sumber dari PADes, Transfer dan juga dari pendapatan lain-lain yang diberikan kepada desa, yang kesemuanya ini diatur melalui Anggaran Pendapatan dan Belanja Desa (APBDes). Kepala desa adalah sebagai kepala pemerintahan di desa dan juga penanggungjawab dalam pengelolaan keuangan desa, dengan dibantu oleh bendahara yang ditunjuk sendiri oleh kepala desa tersebut.

$4 \quad$ I Wayan Surpha, 2004, Eksistensi Desa Adat dan Desa Dinas di Bali, Pustaka Bali Post, Denpasar, hlm.5-6.

Hanif Nurcholis, 2011, Pertumbuhan dan Penyelenggaraan Pemerintahan Desa, Erlangga, Jakarta, hlm.65.
Pemerintahan Desadalam menjalankan kegiatannya diwajibkan untuk membuat APBDes, ini dikarenakan melalui APBDes kebijakan desa yang dijabarkan dalam berbagai program dan kegiatan sudah dapat ditentukan anggarannya. Dengan demikian dalam melaksanakan kegiatan pemerintahan desa berupa pelayanan, dan pembangunan dalam satu tahun anggaran sudah dilakukan rancangan anggarannya, baik pendapatan maupun pengeluarannya, sehingga dapat dilaksanakannya kegiatan tersebut.

Sebagai peraturan pelaksana dari UU yang mengatur tentang Desa tersebut, Permendagri No. 113 Tahun 2014 tentang Pengelolaan Keuangan Desaini mengatur bagaimana cara untuk mengelola pendapatan yang diterima oleh desa. Mengingat pula bahwa undang-udang yang mengatur tentang desa ini diawal kemunculannya akan memberikan dana desa kepada Desa tersebut.

Danadesadisinitermasukkedalamdana transfer, dana transfer merupakan bantuan dari pemerintah pusat yang bersumber pada APBN. Dana desa ini nantinya dipergunakan untuk kepentingan pembangunan dan kesejahteraan masyarakat desa. Namun pemberian dana desa ini apabila kita melihat dalam Permendagri pengelolaan keuangan yang baru ini tidak memberikan dana desa tersebut kepada Desa Adat. Sehingga dalam permendagri ini tidak mengatur mengenai pemberian dana desa tersebut kepada desa adat, maka dari itu latar belakang tersebut menarik bagi penulis untuk membuat karya ilmiah berjudul "Pemberian Dana Desa Kepada Desa Adat di Bali Berdasarkan Permendagri No. 113 Tahun 2014 tentang Pengelolaan Keuangan Desa". 


\subsection{Rumusan Masalah}

Berdasarkan permasalah diatas maka tulisan ini memiliki dua permasalahan, yakni:

1. Bagaimanakah dasar pemberian dana desa kepada desa adat di Bali?

2. Bagaimanakah pertanggungjawaban atas dana desa yang diberikan kepada desa adat?

\subsection{Tujuan Penelitian}

Penelitian yang dilakukan ini tentunya memiliki tujuan, yaitu tujuan umum dan tujuan khusus yaitu:

1. Tujuan umumnya yaitu agar dapat mengetahui bagaimana peberian dana desa kepada Desa Adat.

2. Tujuan khususnya yaitu untuk mengetahui dasar dari pemberian dana desa yang diberikan kepada desa adat, serta untuk mengetahui bagaimana pertanggungjawaban desa adat atas dana desa tersebut.

\section{Metode Penelitian}

Dalam metode penelitian terdapat beberapa hal yang perlu diketahui yaitu :

\subsection{Jenis Penelitian}

Dalam penelitian ini menggunakan penelitian hukum normatif, yaitu meneliti kaidah-kaidah hukum dalam suatu peraturan perundangan yang mengatur mengenai dana desa kepada Desa Adat.

\subsection{Jenis Pendekatan}

Penelitian terhadap pembagian dana desa kepada desa adat di bali ini dilakukan dengan menggunakan pendekatan perundangan serta análisis terhadap konsep hukum.

\subsection{Sumber Bahan Hukum}

Sumber bahan hukum primer dalam penelitian ini yaitu peraturan yang terkait dengan pemberian dana desa kepada desa adat di Bali. Sumber bahan hukum sekunder disini berupa kamus, dan literatur. ${ }^{6}$

\subsection{Teknik Pengumpulan Bahan}

Teknik dalam mengumpulkan bahan disini dilakukan dengan mengumpulkan serta menyortir literatur dan peraturan ${ }^{7}$ yang terkait dengan permasalahan pembagian dana desa kepada desa adat di Bali.

\subsection{Teknik Analisis}

Penelitian ini melakukan olahan terhadap bahan hukum yang tersedia tersebut dengan cara kualitatif. Analisa kualitatif merupakan suatu cara dalam menganalisa yang berbentuk penjelasan dan pendeskripsian. ${ }^{8}$ Analisa kualitatif dalam penelitian ini menjelaskan dan menggambarkan tentang pemberian dana desa kepada desa adat di Bali.

\section{HASIL DAN PEMBAHASAN}

\subsection{Dasar Pembagian Dana Desa Kepada Desa Adat di Bali}

Desa adat telah ada dan berkembang di Bali sebelum datangnya belanda dan memasukkan Desa Dinas dala sistem pemerintahan desa di Bali. Desa adat sebenarnya telah diakui dalam Pasal 18 ayat (2) UUD 1945 yaitu kesatuan-kesatuan masyarakat hukum adat serta hak-hak tradicional yang melekat padanya itu diakui dan dihormati oleh negara, yang mana kesatuan masyarakat tersebut masih hidup

Soerjono Soekanto, 2006, Pengantar Penelitian Hukum, UI Press, Jakarta, hlm.52.

Johny Ibrahim, 2005, Teori dan Metodologi Penelitian Hukum Normatif, Bayu Media, Malang, hlm.284.

Amiruddind an Zainal Asikin, 2004, Pengantar Metode Penelitian Hukum, PT. Raja Grafindo Persada, Jakarta, hlm.167. 
dan berjalan sesuai dengan perkembangan dari masyarakat desa itu sendiri dan tidak melenceng dari prinsip dasar NKRI, sehingga tidak menimbulkan terpecahnya Negara Indonesia menjadi negara-negara kecil. Dari hal tersebut, maka desa adat dan desa dinas nampak diakui dalam sistem pemerintahan di Indonesia. Hak asal usul yang dimiliki oleh desa adat ini merupakan hak yang asli dan hak yang paling besar dimiliki oleh desa adat dibandingkan dengan desa pada umumnya. Dari segi historisnya desa adat disini merupakan suatu kesatuan dari masyarakat hukum adat, desa adat disini memiliki batas wilayah dan memiliki suatu identitas budayanya masing-masing, yang nantinya desa adat ini dengan hak asal usulnya berwenang mengatur dan mengurus kepentingan dari masyarakat suatu desa adat di bali. Komponen yang membentuk adanya masyarakat hukum adat disini yaitu keturunan dan wilayah. ${ }^{9}$

Desa adat merupakan identitas dari pulau bali yang memiliki unsur dasar yaitu agama, adat dan budaya, ketiga hal ini tidak dapat dipisahkan dari Desa Adat dan juga tidak dapat dilepaskan dari bali. Seperti yang dikemukakan oleh Raechelle Rubinstein yaitu "Balinese tend to agree that so long as the are aware of the invisible unity of religion, tradition, and cultura, their identity will remain intact". ${ }^{10}$ Sehingga desa adat harus terus dilestarikan ditengah globalisasi yang semakin menggerus mental masyarakat. Desa adat inilah yang akan terus menjaga

9 Ni'matul Huda, 2015, Hukum Pemerintahan Desa, Setara Press, Malang, hlm.113-114.

10 Raechelle Rubinstein dan Linda Connor, Staying Local in The Global Village Bali in The Twentieth Century, 1999, University Of Hawaii Press, Honolulu Hawaii, hlm.17. dan melestarikan keaslian dari Bali itu sendiri ditengah-tengah pesatnya kemajuan desa di Bali. Agar tidak menjadi desa yang tertinggal perkembangannya dibandingkan dengan desa dinas, maka desa adat harus diperhatikan oleh pemerintah sesuai dengan UU tentang Desa yang mengakui hakhak kesatuan masyarakat adat, termasuk hak untuk mengatur dan mengurus dirinya sendiri.

Dalam menjalankan kewenangan yang dimilikinya, desa adat tentu memerlukan dana agar program-program yang direncanakan oleh desa adat dapat dijalankan dengan baik, terutama program yang berkaitan dengan pelestarian budaya, adat serta agama.

Mengenai dana desa yang dapat diberikan kepada desa adat sebenarnya telah diatur dalam Permendesa tentang prioritas penggunaan dana desa, dalam Pasal 2 yang menyatakan bahwa dana desa yang bersumber dari APBN diberikan kepada desa yang kemudian disebut dana desa dan digunakan untuk mendanai segala kegiatan yang berdasarkan atas kewenangan asal usulnya, yang mana aturannya ini diatur sendiri oleh desa tersebut. Kewenangan yang berskala desa dan berdasar atas hak asal usul ini yaitu hak yang dimiliki oleh Desa Adat di Bali, sehingga dengan dasar ini Desa Adat di Bali berhak untuk diberikan Dana Desa dari pusat tersebut.

Ditegaskan pula dalam pasal 3 yang menyatakan bahwa kewenangan yang berasal dari hak asal usul desa ini meliputi :

a. Penataan dalam sistem organisasi dan juga penataan dalam kelembagaan pada suatu masyarakat adat.

b. Penataan hukum yang terdapat dalam masyarakat adat. 
c. Hak memiliki kepemilikan tradicional pada masyarakat hukum adat.

d. Hak untuk mengelola tanah kas Desa Adat.

e. Hak dalam mengelola tanah ulayat. Sehingga dari uraian tersebut diatas, Desa Adat tentu mendapatkan dana desa dari pusat. Besaran dana desa yang didapat oleh Desa Adat di Bali tentunya akan dihitung berdasarkan jumlah Desa Adat yang dimiliki dalam suatu kabupaten/kota di Bali.

Selain dana desa tersebut Desa Adat juga mendaaptkan dana Bantuan Keuangan Khusus (BKK) yang diberikan kepada desa adat dan subak di bali. Danabantuan keuangan khusus inidiberikan oleh Pemerintah Provinsi Bali guna memberdayakan masyarakat Desa Adat dan Subak yang merupakan aset kebudayaan Provinsi Bali.

Dengan dikeluarkannya Permendagri yang baru ini yang mengatur tentang pengelolaan keuangan desa, desa adat dan subak dibali tidak langsung mendapatkan dana bantuan keuangan khusus yang diberikan oleh Pemerintah Provinsi Bali tersebut. Namun apabila didasarkan pada Permendagri sebelumnya yang telah lebih dulu mengatur mengenai pengelolaan keuangan desa ini, Desa Adat dan Subak secara langsung mendapatkan dana Bantuan Keuangan Khusus atau yang sering disebut BKK ini.

Dengan adanya Permendagri yang baru tersebut, BKK atau Bantuan Keuangan Khusus tidak akan langsung diberikan kepada Desa Adat dan Subak oleh Dinas Kebudayaan Provinsi Bali, namun melalui Desa Dinas yang aturannya tersebut telah diaturdalamPermendagriyangbarumengatur tentang pengelolaan keuangan desa tersebut.
Sehingga Desa Adat berhak atas dana desa yang diberikan oleh pusat dan juga berhak berhak atas dana bantuan keuangan khusus yang diberikan oleh Provinsi berdasarkan ketentuan-ketentuan yang berlaku.

Sehingga Desa Adat nantinya berhak atas dana desa dan dana BKK yang pemberiannya dilakukan melalui Desa Dinas, sehingga segala kegiatan yang berkaitan dengan kewenangan yang dilakukan oleh desa adat tersebut telah dirumuskan dalam APBDes terlebih dahulu sebelum dijalankan dan direalisasikan oleh Desa Adat.

\subsection{Pertanggungjawaban Dana Desa Yang Diberikan Kepada Desa Adat}

Bali sebagai suatu daerah yang memiliki keanekaragaman yang cukup tinggi baik dari segi adat istiadat, budaya maupun masyarakatnya yang heterogen ini memiliki dua jenis desa yang selama ini berjalan beriringan dalam menghadapi perkembangan dari suatu desa.

Sampai sekarangpun Bali tidak melakukan pemilihan terhadap desa mana yang dipilih, meskipun telah diatur untuk dilakukannya pemilihan tersebut. Konsekuensi dari tidak mendaftarkan salah satu desa ini tentu saja berkaitan dengan dana desa yang akan didapat oleh desa yang didaftarkan ke pusat tersebut.

Dana desa merupakan bantuan oleh pemerintah pusat yang sangat diharapkan oleh desa semenjak UU desa ini diundangkan, baik oleh desa dinas maupun desa adat. Dana desa ini sebagai penunjang dalam menjalankan roda pemerintahan guna meningkatkan fasilitas dan kesejahteraan bagi masyarakat desa. 
Dana desa yang diberikan ke desa ini disesuaikan dengan jumlah penduduk, luas wilayah serta kondisi masyarakat suatu desa tersebut. Sehingga pemberian dana desa diharapkan menjadi tepat sasaran.

Pemberian dana desa sebagai program dari pemerintah ini diharapkan membuat desa menjadi lebih mandiri dalam mengatur pemerintahan serta anggarannya sendiri. Pengelolaandanadesainimerupakankegiatan perencanaan, pelaksanaan, penatausahaan, pelaporan dan pertanggungjawaban keuangan desa.

Dana desa merupakan dana pusat yang bersumber dari APBN dan nantinya diberikan kepada pemerintah desa yang digunakan dalam membiayai penyelenggaraan pemerintahan desa. Sehingga pemberian dana desa kepada desa adat digunakan untuk melaksanakan atau menyelenggarakan urusan adat istiadat dan agama sebagai kewenangan desa adat.

Kewenangan dalam mengelola dana desa yang diberikan kepada desa adat tentunya menimbulkan berbagai kewajiban yang diakibatkan oleh diberikannya dana tersebut oleh pemerintah pusat. Desa Adat diharapkanmampumenjaga danmelestarikan kekayaan budaya yang menajadi daya Tarik dari pulau Bali.

Tidak hanya memberikan dana pusat tersebut kepada desa adat, namun juga memberikan dana BKK keada Desa Adat, yang nantinya dengan pendapatan yang diperoleh oleh desa adat tersebut dapat dipergunakan menjalankan kewenangannya sehingga menjaga kelestarian adat dan budaya Bali.
Penggunaan dana desa ataupun BKK ini dipergunakan sepenuhnya untuk menjalankan kewenangan adat, agama, dan juga untuk pemberdayaan subak. Subak merupakan organisasi pengairan sawah pada masyarakat bali yang gunanya untuk meningkatkan taraf hidup ekonomi petani.

Subak disini merupakan wadah masyarakat adat yang bersifat sosial religius yang tumbuh dan berkembang sebagai organisasi tata pengairan sawah di tingkat petani desa. Organisasi subak ini dilandaskan atas filosofi Tri Hita Karana yaitu meliputi hubungannya dengan Ketuhanan, Hubugan manusia dengan sesama manusia, serta hubungan manusia dengan lingkungannya, yang mana hal ini merupakan dasar dalam menjaga keharmonisan dan kelestarian lingkungan di Bali. ${ }^{11}$

Keseluruhan dana desa dan juga dana BKK yang diberikan kepada Desa Adat sebelum dilimpahkan kepada Desa Adat terlebih dahulu dimasukkan kedalam APBDes Desa Dinas. Ini dikarenakan desa dinaslah yang diakui dalam sistem pengelolaan keuangan desa yang didasarkan atas Permendagri tentang pengelolaan keuangan desa yang baru tersebut.

Meskipun dana desa ini diberikan kepada desa adat, namun mekanismenya yang dipilih tetap melalui desa dinas, sehingga menimbulkan kesan bahwa desa adat dibali berada dibawah desa dinas, meskipun diakui kedua-duanya.

I Gede Suartika, 2010, Anatomi Konflik Adat di Desa Pakraman dan Cara Penyelesaiannya, Udayana University Press, Denpasar, hlm.47. 
Mekanisme pemberian dana kepada Desa Adat ini yaitu dengan dana desa yang diberikan oleh pemerintah pusat maupun dana Bantuan Keuangan Khusus (BKK) yang diberikan oleh Provinsi Bali kepada desa adat ini ditransfer terlebih dahulu ke rekening APBDes dari desa dinas.

Setelah dimasukkan kedalam APBDes barulah dapat diberikan kepada desa-desa adat yang berada di wilayah desa dinas tersebut. Dengan dimasukkannya dana desa dan dana BKK tersebut kedalam APBDes, dalam melaksanakan kegiatan dari desa adat, baik itu yang berkaitan dengan adat maupun keagamaan, harus dilakukan pertanggungjawaban pelaksanaan anggaran yang diwujudkan dalam Surat Pertanggungjawaban (SPJ) yang nantinya Desa Dinas pada akhir masa anggaran melaporkan realisasi dari dana yang masuk kedalam APBDes tersebut.

Kepala Desa Dinas sebagai penanggungjawab pelaksanaan dari APBDes ini menerima pertanggungjawaban dari desa-desa adat di wilayah desa dinasnya, sehingga Kepala Desa Dinas yang nantinya menyampaikan pertanggungjawaban realisasi anggaran tersebut kepada Bupati/ Walikota pada tiap akhir dari tahun anggaran yang bersangkutan.

Setelah diterima oleh Bupati/ Walikota, selanjutnya Bupati/Walikota juga melaporkan realisasi dana ini kepada Provinsi dan selanjutnya Provinsi melaporkan kembali kepusat. Proses pelaporan hasil pertanggungjawaban anggaran yang berjenjang ini memberi manfaat untuk saling mengkoreksi hasil dari realisasi anggaran yang dipergunakan tersebut.
Banyaknya dana yang akan dikelola oleh Desa Adat ini, maka desa adat sebaiknya meningkatkan SDM dari aparatur desa adat tersebut, agar meminimalisir ketidaktahuan akan penggunaan anggaran dan cara dalam mempertanggungjawabkannya.

\section{SIMPULAN DAN SARAN \\ a. Kesimpulan}

Berdasarkan uraian tersebut, maka dasar dari pemberian dana desa kepada desa adat di bali yaitu didasarkan pada Permendagri yang lama yang mengatur mengenai pengelolaan keuangan desa, yang mana hal ini dilakukan karena Permendagri yang baru tidak dapat mengatur mengenai pemberian dana desa tersebut kepada desa adat. Sedangkan dana desa yang diberikan kepada desa adat dilakukan melalui APBDes dari desa dinas, sehingga segala pengeluaran yang dikeluarkan dari APBDes tersebut mewajibkan untuk adanya Surat Pertanggungjawaban (SPJ) termasuk penggunaan dana tersebut oleh Desa Adat.

\section{b. Saran}

Harus dibuatnya pengaturan mengenai penggunaan dana yang dilakukan oleh desa adat dan diharapkan dibuatnya mekanisme tertentu agar pertanggungjawaban ini bisa langsung dilakukan oleh Desa Adat sehingga tidak melalui Desa Dinas.

\section{DAFTAR BACAAN}

\section{Buku}

Amiruddin dan Zainal Asikin, 2004, Pengantar Metode Penelitian Hukum, PT. Raja Grafindo Persada, Jakarta.

Dharmayudha, I Made Suastawan, 2001, Desa Adat Kesatuan Masyarakat 
Hukum Adat di Provinsi Bali, Upada Sastra, Denpasar.

Huda, Ni'matul, 2015, Hukum Pemerintahan

Desa, Setara Press, Malang.

Ibrahim Jhony, 2005, Teori dan Metodologi

Penelitian Hukum Normatif, Bayu

Media, Malang.

Kaelan, 2004, Pendidikan Pancasila, Paradigma, Yogyakarta.

Nurcholis, Hanif, 2011, Pertumbuhan dan

Penyelenggaraan Pemerintahan Desa,

Erlangga, Jakarta.

Rubinstein, Raechelle dan Linda Connor,

Staying Local in The Global Village

Bali in The Twentieth Century, 1999,

University of Hawaii Press, Honolulu

Hawaii.

Soekanto, Soerjono, 2006, Pengantar

Penelitian Hukum, UI Press, Jakarta.

Suartika, I Gede, 2010, Anatomi Konflik

Adat di Desa Pakraman dan Cara

Penyelesaiannya, Udayana University

Press, Denpasar.

Surpha, I Wayan, 2004, Eksistensi Desa Adat dan Desa Dinas di Bali, Pustaka

Bali Post, Denpasar.

\section{Perundang-Undangan}

UUD 1945

UU No.6 Tahun 2014 tentang Desa

Permendagri No. 37 Tahun 2007 tentang

Pedoman Pengelolaan Keuangan Desa

Permendagri No. 113 Tahun 2014 tentang

Pengelolaan Kuangan Desa

Permendesa No. 5 Tahun 2015 tentang

Penetapan Prioritas Dana Desa. 